\title{
ADAPTATION AND CONSERVATION OF THE FINE ARTS MUSEUM IN THE KASATRIYAN COMPLEX AT THE KERATON OF YOGYAKARTA
}

\author{
${ }^{1}$ Arthur Pramudya. ${ }^{2}$ Dr. Ir. Alwin Suryono S., M.T. \\ ${ }^{1}$ Student in the Bachelor's (S-1) Study Program in Architecture at \\ Parahyangan Catholic University \\ ${ }^{2}$ Senior lecturer in the Bachelor's (S-1) Study Program in Architecture \\ at Parahyangan Catholic University
}

\begin{abstract}
At present, the Fine Arts Museum at the Keraton of Yogyakarta is still intact, though it has seen slight change and is less than comfortably equipped for certain activities. This research study aims to reveal the cultural significance of the objects and the architectural elements that have shaped them, followed by a description of preservation measures. The research method is qualitative-interpretative, along with the Architectural Approach (function-form-meaning), Architectural Typology, and the Conservational Approach. The cultural significance of the formal aspects falls under architectural values and skills, whereas the functional aspect takes on the form of purpose-based values and history-related values.

The building with its massive shape has been adapted to its environment or immediate surroundings, in addition to having been ornamented. The spatial arrangement shows a symmetrical pattern. The thick walls protect it against the local tropical climate. The function of the building has changed drastically, namely from being a school to a residence for the Crown Prince, to its final transformation into a museum. The ornaments on the ceiling, railings, walls, gable and columns reveal a decidedly mixed style consisting of Art Nouveau, the typical Indies style, and local Javanese architecture. The skill-related values reveal the technology behind the shaping elements of the structural and architectural construction. The current purpose-based values refer to its present use as a Fine Arts Museum.

The period spanning 1921-1934 forms the reference point for conservation. The condition of the building is still intact and solid, but there is some ambiguity in terms of temporal context (era) discernible, and there is minor damage, as well as less than satisfactory suitability for its current purpose. Conservation measures include adaptation of the building in accordance with its current function and preservation in the shape of routine maintenance.
\end{abstract}

Keywords: Fine Arts Museum, cultural meaning, adaptation, conservation

\section{ADAPTASI DAN PRESERVASI MUSEUM LUKISAN KOMPLEK KASATRIYAN, KERATON YOGYAKARTA}

\author{
${ }^{1}$ Arthur Pramudya. ${ }^{2}$ Dr. Ir. Alwin Suryono S., M.T. \\ ${ }^{1}$ Mahasiswa S1 Program Studi Arsitektur Universitas Katolik Parahyangan. \\ 2 Dosen Pembimbing S1 Program Studi Arsitektur Universitas Katolik Parahyangan.
}

\footnotetext{
${ }^{1}$ Corresponding author: atutarthur@gmail.com
} 


\begin{abstract}
Abstrak- Kondisi Museum Lukisan Komplek Kasatriyaan di Keraton Yogyakarta saat ini masih utuh, namun mengalami beberapa perubahan dan berkurangnya kenyamanan untuk beraktivitas. Studi ini mengungkap nilainiai dan periode pembangunan setiap elemen bangunan. Teori Capon digunakan untuk melihat susunan elemen arsitektur berupa fungsi-bentuk-makna. Teori pelestarian Piagam Burra Charter sebagai pendekatan Makna Kultural, yang dipertahankan melalui tindakan pelestarian. Tipologi Arsitektur oleh Hadinata dan Sidharta Budihardjo untuk penjabaran nilai arsitektur setiap elemen bangunan, dan ICOM (International Council of Museum) sebagai pedoman tindakan pelestarian pada museum. Metoda yang digunakan ialah kualitatifinterpertasi. Fungsi-bentuk-makna dideskripsikan pada obyek, sekaligus sebagai acuan Makna Kultural, yaitu: aspek bentuk berupa Nilai Arsitektur dan Kekriyaan, aspek Fungsi berupa Nilai Guna Bangunan, dan aspek Makna berupa nilai Kesejarahan. Hasil Penelitian. "Fungsi": Dinding tebal sebagai struktur bangunan dan sebagian sebagai perlindungan terhadap iklim lokal, ornamentasi menggambarkan pencampuran budaya luar dengan lokal. Mengalami perubahan fungsi dari sebuah sekolah dan tempat tinggal putra mahkota, menjadi museum lukisan. Makna Kultural berupa Nilai Arsitektural, Kekriyaan, Kesejarahan dan Nilai Guna bangunan. Nilai Arsitektural: elemen pembentuk bangunan berupa pencampuran gaya dari berbagai budaya, Nilai Kesejarahan: fungsi bangunan sebelumnya sebagai sekolah dan tempat tinggal putra mahkota. Nilai Kekriyaan: Teknologi pembentukan elemen pada bangunan, baik struktural maupun arsitektural. Kondisi bangunan masih utuh dan kokoh, namun terdapat keambiguan zaman pada elemen pembentuk bangunan, kerusakan minor berupa kotor, karat, dan pudarnya warna, juga kurangnya kenyamanan sebagai sebuah museum lukisan. Tindakan pelestariannya ialah Adaptasi, perubahan fasad, kenyamanan termal dan pencahayaan dalam ruangan, lalu preservasi berupa perawatan rutin.
\end{abstract}

Kata kunci: Museum Lukisan, makna kultural, adaptasi, preservasi

\title{
1 PENDAHULUAN
}

\subsection{LATAR BELAKANG MASALAH}

Daerah Istimewa Yogyakarta merupakan wilayah tertua kedua di Indonesia, yang dibentuk oleh pemerintah negara bagian Indonesia. Pada 13 Februari 1755 Sri Sultan Sultan Hamengkubuwono I mendirikan sebuah kompleks bangunan di Yogyakarta dengan nama Keraton. Kemenarikan bangunan Keraton Yogyakarta bukan hanya terletak pada arsitektur Jawa, tetapi lebih-lebih pada kandungan nilai-nilai kultural-edukatif yang visualisasinya nampak dalam simbol-simbol. Melalui bangunan Keraton nilai-nilai luhur yang telah tersaring dari berbagai rekaman sejarah dan budaya secara non-verbal divisualisasi dan disosialisasikan agar menjadi sumber inspirasi yang tidak pernah kering bagi setiap generasi dalam memperjuangkan keluhuran martabat manusia. Nilai kebudayaan yang dimiliki oleh Keraton Yogyakarta sudah sepatutnya dikenal oleh orang banyak, baik itu secara Nasional ataupun Internasional, sehingga akan menarik wisatawan mancanegara ataupun domestik untuk datang dan mengunjungi Keraton Yogyakarta. Hal ini tentunya akan menjadi magnet untuk bidang pariwisata di wilayah Daerah Istimewa Yogyakarta. Potensi Keraton Yogyakarta dalam kepariwisataan tentunya sangat tinggi, bahkan rencananya Keraton Yogyakarta akan dijadikan BCB (Bangunan Cagar Budaya) bertaraf Internasional. ${ }^{2}$

Komplek Kesultanan Keraton Yogyakarta terdiri atas 2 jenis bangunan, bangunan yang terbuka di area tengah komplek disebut dengan bangsal, sedangkan bangunan yang menggunakan dinding di area pinggiran disebut dengan Gedhong. Keraton terdiri atas puluhan objek yang merupakan cagar budaya.

Salah satu diantaranya adalah Komplek Kasatriyan, dibangun pada masa pemerintahan sultan Hamengkubuwono VII (kejayaan tahun 1839 - 1921) pada tahun 1896. Komplek Kasatriyan berfungsi sebagai sekolah dan tempat tinggal putra mahkota. Salah satu Gedhong

\footnotetext{
${ }^{2}$ Artikel ini disunting dari penelitian yang dikerjakan oleh Fitriani Sondari (2011), berjudul Tugas Karya Ilmiah: Keraton Yogyakarta, diringkas oleh Arthur Pramudya mahasiswa Jurusan Arsitektur Universitas Katolik Parahyangan.
} 
di Komplek Kasatriyan pernah ditinggali oleh putra mahkota dari Sultan Hamengkubuwono VII, yaitu Gatot Kaca.

Komplek Kasatriyan ini merupakan salah satu area pembangunan yang dipengaruhi oleh budaya kolonial. Keunikan dari Komplek Kasatriyan adalah keberadaan langgam kolonial yang bersatu dengan langgam arsitektur lokal. Kedua tipe bangunan secara harmonis berdiri di sebuah tempat dimana banyak kegiatan berlangsung.

Pada tahun 1921 hingga 1934 dilakukan konservasi besar-besaran terhadap keseluruhan komplek kesultanan yang dilakukan oleh Sultan Hamengkubuwono VIII untuk menjaga keunikan dan keindahan komplek tersebut agar layak digunakan beraktivitas, dan mampu meningkatkan kegiatan kesenian dan kebudayaan.

Pada tahun 1988, Sultan Hamengkubuwono IX melakukan pemugaran terhadap Kompleks bersejarah Keraton, hal ini melibatkan sebagian Kompleks Kasatriyan mengalami perubahan fungsi menjadi museum lukisan. Sedangkan tindakan yang dilakukan antara lain, mengecat kembali elemen bangunan, memperbaiki atap, dinding dan seluruh ruangan yang sebelumnya telah rusak parah. Selain itu mengganti bagian-bagian yang sudah tidak dapat dipertahankan secara struktural.

Kompleks Kasatriyan tidak mengalami renovasi maupun rekonstruksi, sedangkan hanya mengalami rehabilitas atau penambahan elemen bangunan, untuk menambah kekokohan bangunan dan nilai estetik dari kasatriyan.

Namun seiring terjadinya pembaharuan terhadap bangunan, terbentuk kemungkinan berkurangnya nilai-nilai kesejarahan bangunan, hingga kehilangan makna yang dikandungnya. Lebih lagi akibat perubahan fungsi, sehingga tercipta kebutuhan akan kenyamanan beraktivitas di setiap ruangnya. Sayangnya saat ini belum dilakukan tindakan apapun untuk menciptakan kenyamanan beraktivitas di dalam ruangan-ruangannya.

\subsection{PERUMUSAN MASALAH}

Dari rumusan di atas, maka dapat diajukan pertanyaan sebagai berikut:

(1) Keistimewaan apa yang dimiliki Museum Lukisan di Komplek Kasatriyan, sehingga layak dikonservasi?

(2) a. Penambahan Elemen apa saja yang telah dilalui Museum Lukisan setiap periodenya?

b. Apakah setiap penambahan elemen memiliki signifikansi pada bangunan? (3) Bagaimana tindakan konservasi guna menjaga kesejarahan dan kenyamanan beraktivitas di Museum Lukisan?

\subsection{TUJUAN DAN MANFAAT PENELITIAN}

Tujuan dari penelitian ini adalah:

(1) Mengetahui keunikan dan keistimewaan yang dimiliki oleh Museum Lukisan Komplek Kasatriyan, sehingga tercipta kebutuhan untuk dilakukan tindakan konservasi.

(2) Mengetahui tahapan yang menciptakan perubahan pada wujud fisik bangunan, untuk mengetahui keseluruhan elemen pada bangunan yang membutuhkan upaya konservasi.

(3) Mengetahui tindakan konservasi dan perawatan bangunan, agar kompleks kasatriyan mampu mempertahankan nilai bangunan, dan kenyamanan aktivitas tetap terjaga. Manfaat dari penelitian ini adalah:

(1) Mengetahui keunikan dan keistimewaan yang dimiliki oleh Museum Lukisan Komplek Kasatriyan, sehingga tercipta kebutuhan untuk dilakukan tindakan konservasi. 
(2) Mengetahui tahapan yang menciptakan perubahan pada wujud fisik bangunan. Tahap ini dibutuhkan untuk menciptakan acuan terhadap tindakan konservasi.

(3) Mengetahui tindakan konservasi pada setiap elemen bangunan guna menjaga kesejarahan dan kenyamanan beraktivitas di Museum Lukisan.

\subsection{OBYEK PENELITIAN}

Pengambilan sampel penelitian merupakan bangunan masa kolonial di Komplek Kasatriyan yang saat ini berfungsi sebagai museum lukisan. Kedua bangunan tersebut adalah Gedhong Maduretna dan Gedhong Pringgodani.

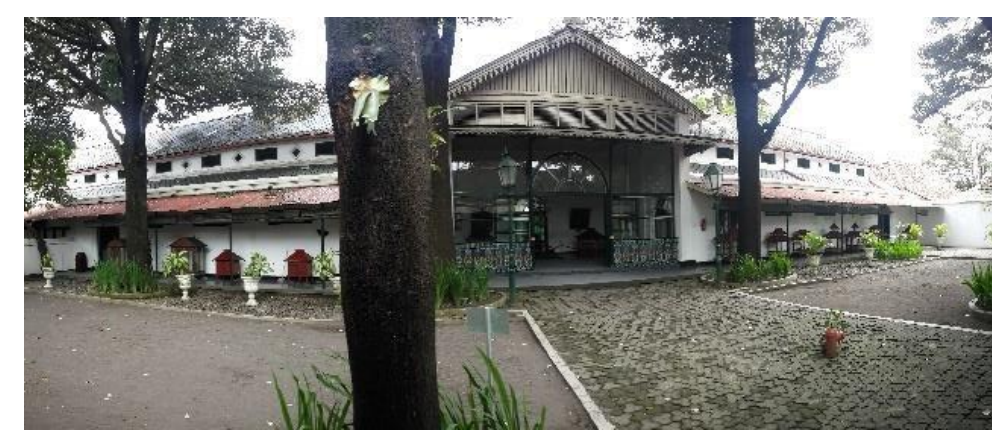

Figur 1. Gedhong Maduretna

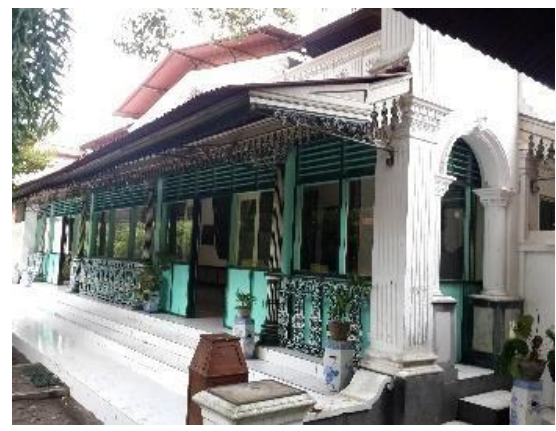

Figur 2. Gedhong Pringgodani

\subsection{BATASAN PENELITIAN}

Batasan penelitian ini adalah teknik konservasi terhadap setiap elemen pada bangunan pencampuran arsitektur kolonial dengan unsur lokal di Komplek Kasatriyan, Keraton Yogyakarta. Wujud dan makna yang tercitra dari setiap periode bangunan saat berfungsi sebagai sekolah dan tempat tinggal putra mahkota dan setelah mengalami perubahan fungsi menjadi sebuah museum lukisan. Juga kenyamanan secara visual maupun termal di dalam standard sebuah museum.

\subsection{METODA PENELITIAN}

Metode yang digunakan dalam penelitian ini merupakan metode kualitatif, yang mencakup observasi aktif, pasif, serta pengambilan data dokumentasi berupa foto dan gambargambar penunjang lain, dibantu oleh studi literatur sebagai penunjang data-data lapangan tersebut.

Metodologi yang terkait juga berupa metode interpretasi, yakni interpretasi dari analisa yang didapat sebagai wujud pemberian nilai makna dan saran konservasi pada objek penelitian untuk menghasilkan kesimpulan yang merupakan jawaban dari pertanyaan penelitian.

\section{KAJIAN TEORI MUSEUM LUKISAN KOMPLEK KASATRIYAN}

\subsection{DATA TEKNIS}

Nama bangunan: Gedhong Maduretna dan Gedhong Pringgodani

Alamat: Keraton Yogyakarta, Jl. Rotowijayan 1, Yogyakarta 55133

Tahun dibangun: 1896

Pembangun: Sultan Hamengkubuwono VII 
Komplek Kasatriyan berfungsi sebagai sekolah dan tempat tinggal putra mahkota. Sekolah mereka dipisahkan dari sekolah rakyat, karena merupakan aturan di Keraton bahwa putra- putra sultan tidak diperbolehkan bersekolah di sekolah yang sama dengan rakyat. Hal tersebut khusus agar pengajaran dilakukan untuk mempersiapkan putra sultan menjadi kesatria dan mempersiapkan diri sebelum pernikahan.

Komplek Kasatriyan ini memiliki keragaman jenis langgam arsitektur. Terdapat bangunan seperti bangsal kasatriyan yang memiliki langgam arsitektur Jawa dan selebihnya dengan langgam campuran arsitektur Jawa dengan arsitektur kolonial (Art Nouveau \& akhir 1900 Indische Empire Style).

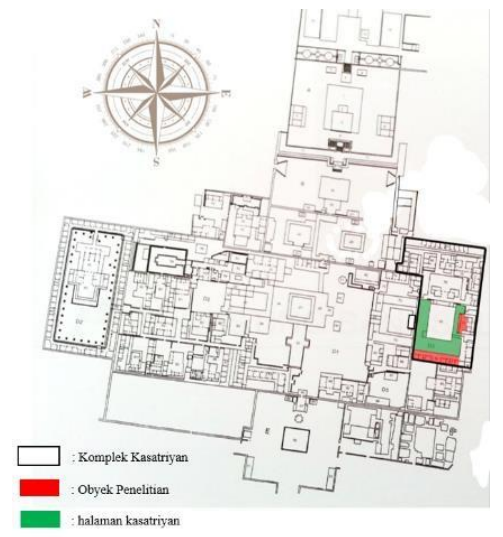

Figur 3. Obyek Peneltian

\subsection{ARSITEKTUR MUSEUM LUKISAN KOMPLEK KASATRIYAN}

\subsubsection{MASIF}

Gedhong Maduretna memiliki bukaan relatif kecil pada bagian sayap kiri dan kanan bangunan. Bukaan berdimensi kecil mencirikan bangunan memiliki gaya arsitektur kolonial yang masif, sehingga memberikan kesan kokoh dan ketertutupan. Pada dasarnya ketertutupan tersebut berkaitan dengan aktivitas penggunanya yaitu sebagai sebuah masjid kasatriyan, dapur, dan gudang peralatan musik yang diletakkan di lantai 2. Pada koridor juga terlihat terdapat beberapa skylight sebagai pencahayaan tanpa mengganggu ketertutupan ruang.

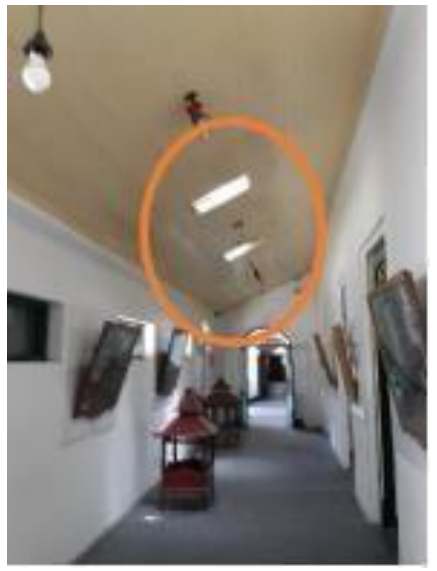

Figur 4. Skylight interior

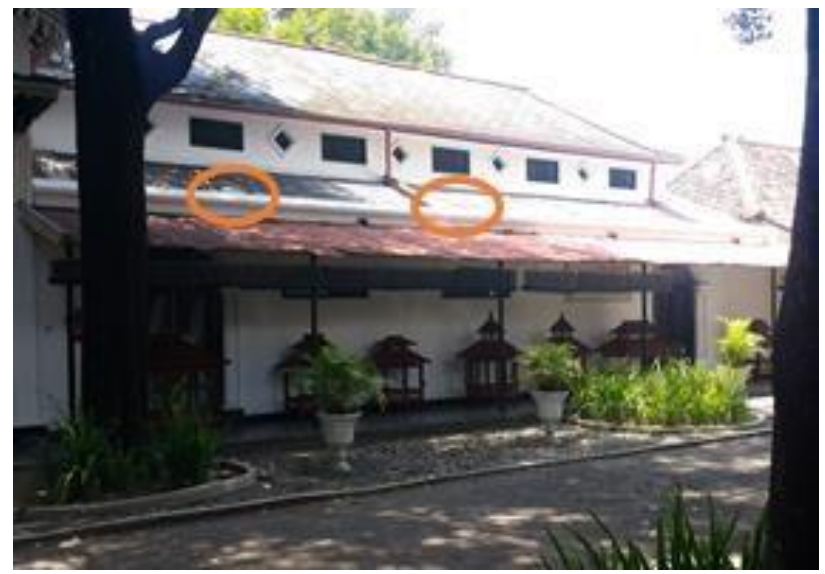

Figur 5. Skylight eksterior

Bagian tengah bangunan memiliki sifat seperti sebuah beranda bangunan Neo-klasik yang dihiasi oleh 2 kolom besar bergaya Yunani dengan penambahan elemen-elemen dekorasi 
bercirikan gaya arsitektur Betawi. Pada tahun 1988 ditambahkan dinding kaca untuk melindungi benda-benda bersejarah dari kerusakan akibat cuaca.

Sebagian besar pintu pada bangunan memiliki bentuk sebuah vault atau arch dan beberapa memiliki kusen kayu berhiaskan kolom-kolom yunani.
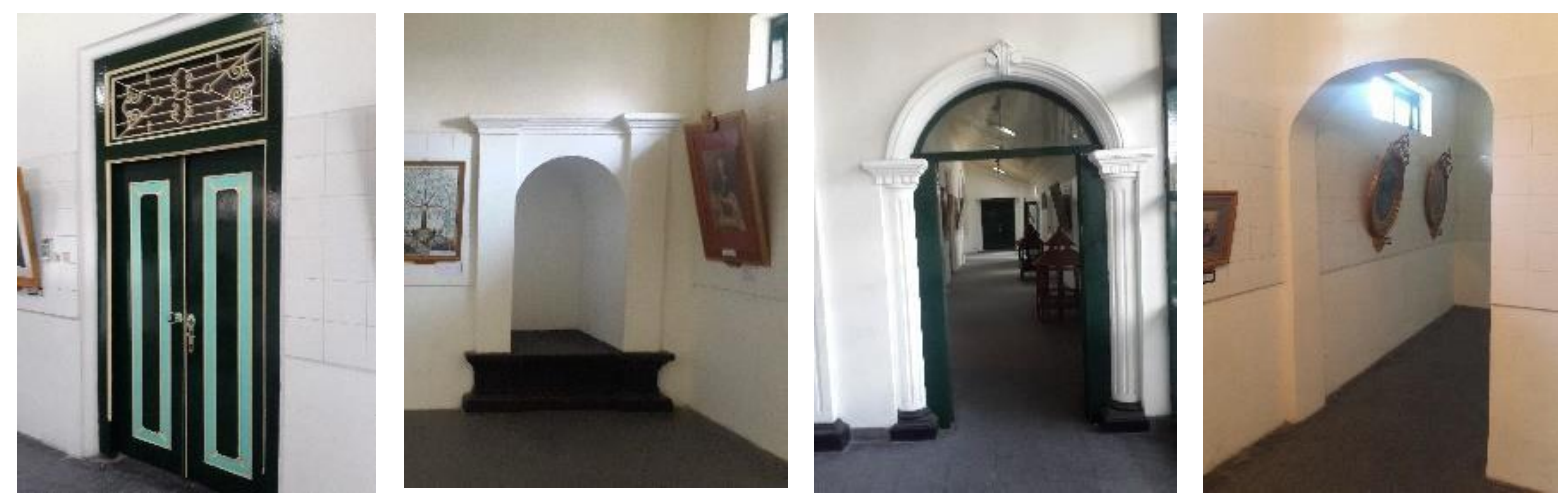

Figur 6. Jenis-jenis pintu pada Gedhong Maduretna

Area pembahasan Gedhong Pringgodani merupakan sebuah teras yang diberikan penambahan dinding partisi dan kolom-kolom besi bergayakan Art Nouveau. Fasad depan sebelum penambahan dinding partisi memiliki kemiripan dengan teras bangunan Neo-Klasik berupa Gevel yang ditumpu oleh kolom-kolom bergaya Art Nouveau.

\subsubsection{SIMETRIS}

Denah tersusun akan bentukan geometris. Terlihat pada denah kedua gedhong memiliki denah simetris dengan axis memendek dari pintu masuk utama, kesimetrisan tersebut juga terlihat pada pembagian ruang pada Gedhong Maduretna. Namun terdapat perbedaan menjadikan bangunan tidak simetris sempurna yang dikarenakan oleh penyatuan massa bangunan antara kedua gedhong sehingga berbentuk sebagai massa pelingkup secara keseluruhan.

Pada denah keseluruhan kasatriyan terbentuk kesimetrisan komponen geometris pembentuk komplek tersebut seperti terlihat pada gambar, dengan tumpuan utama axis menmanjang pada bangsal kasatriyan yang merupakan bangunan utama komplek.

\subsubsection{Ornamen}

\subsubsection{GEVEL}

Gevel merupakan salah satu kekhasan arsitektur kolonial Belanda di Indonesia. Pada bagian gevel Gedhong Maduretna terdapat banyak ornament yang mencirikan arsitektur Art- 


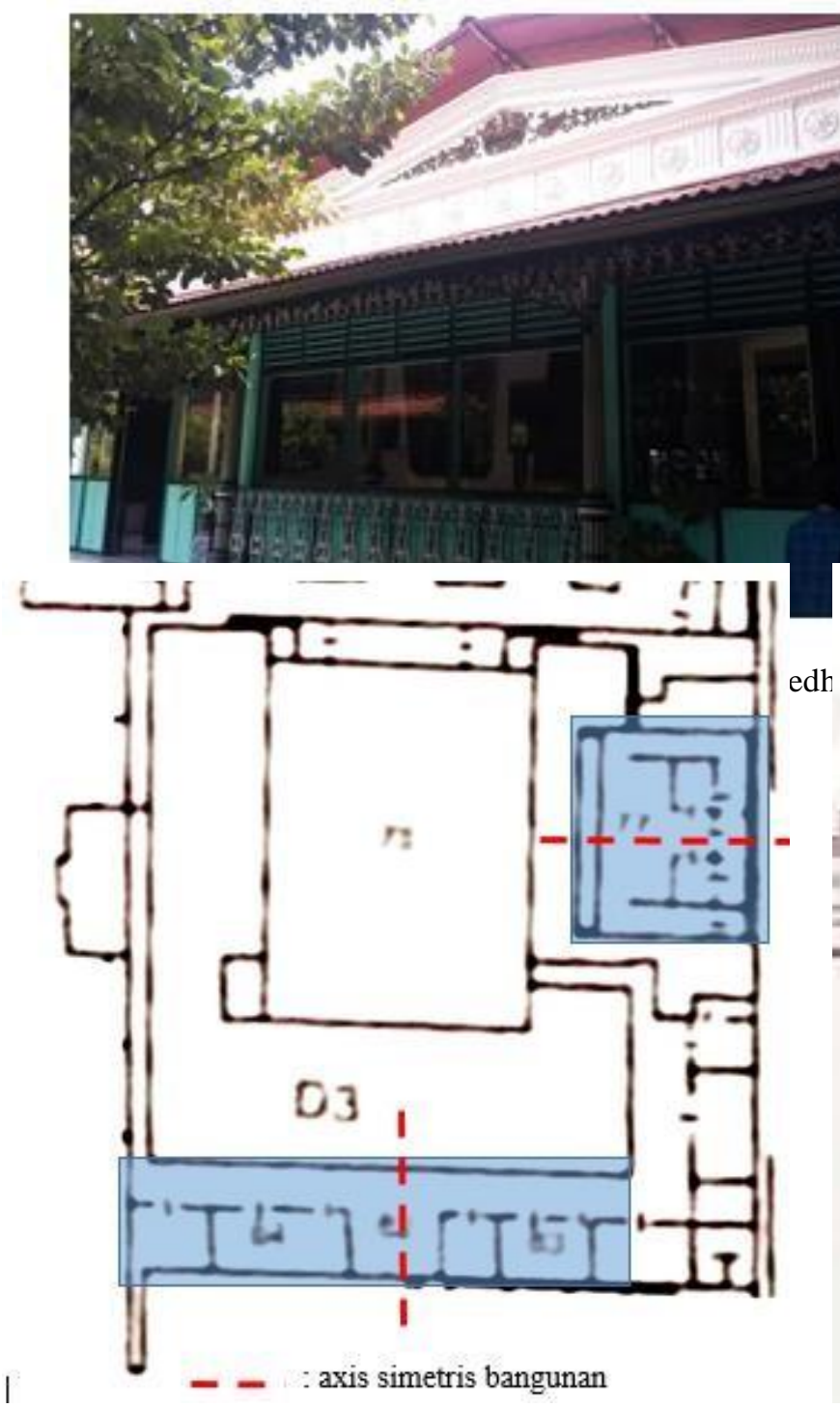

Figur 8. Kesimetrisan Gedhong Maduretna dan Gedhong Pringgodani

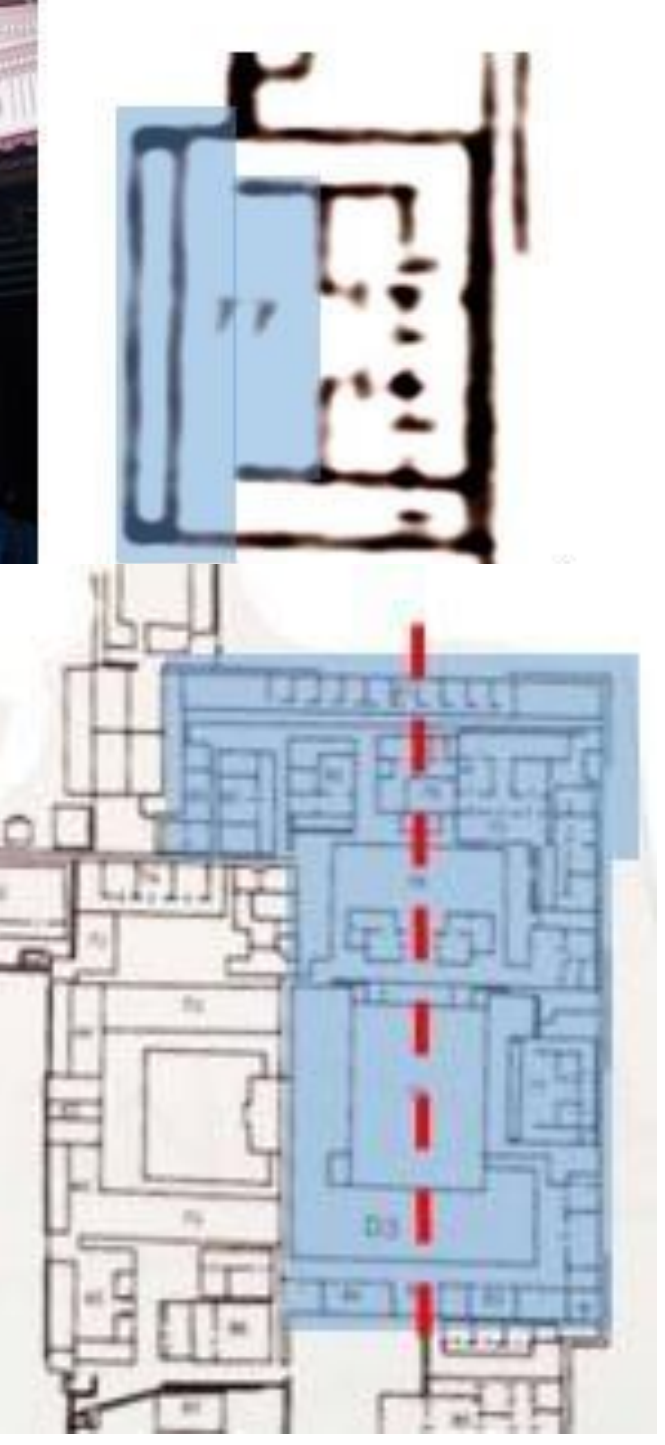

Figur 9. Kesimetrisan Komplek Kasatriyan

Nouveau. Ornmen pada gevel banyak berupa matahari, tali air, dan lambang kerajaan. Sedangkan pada Gedhong Pringgodani, gevel bermaterial kayu menyerupai arsitektur Betawi.

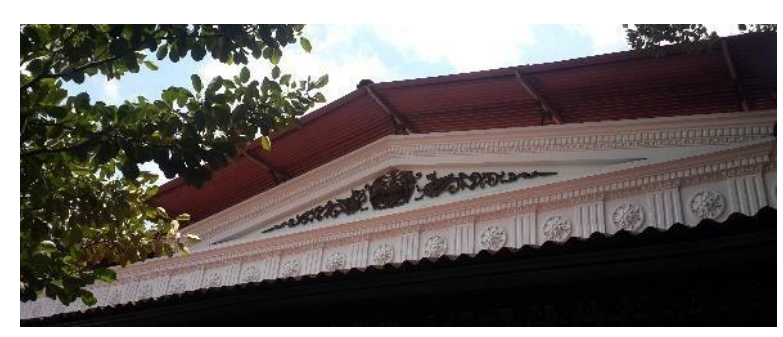

Figur 10. Gevel Gedhong Pringgodani

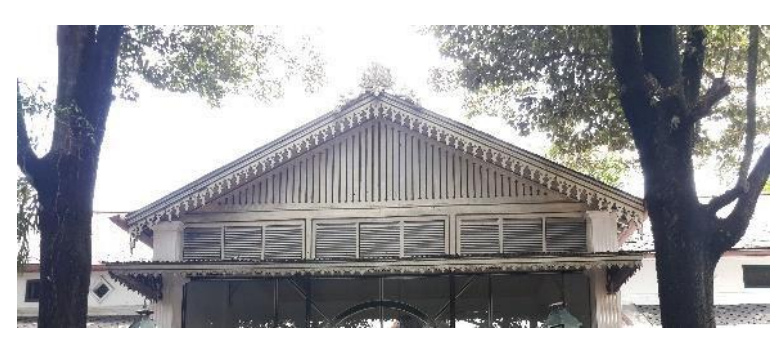

Figur 11. Gevel Gedhong Maduretna

\subsubsection{MOLDING}

Molding pada dasarnya terdapat pada keseluruhan bagian dari bangunan, seperti pada gevel, kolom, dinding interior dan entablature. Beberapa diantaranya berupa tali air dengan ukiran floral. 


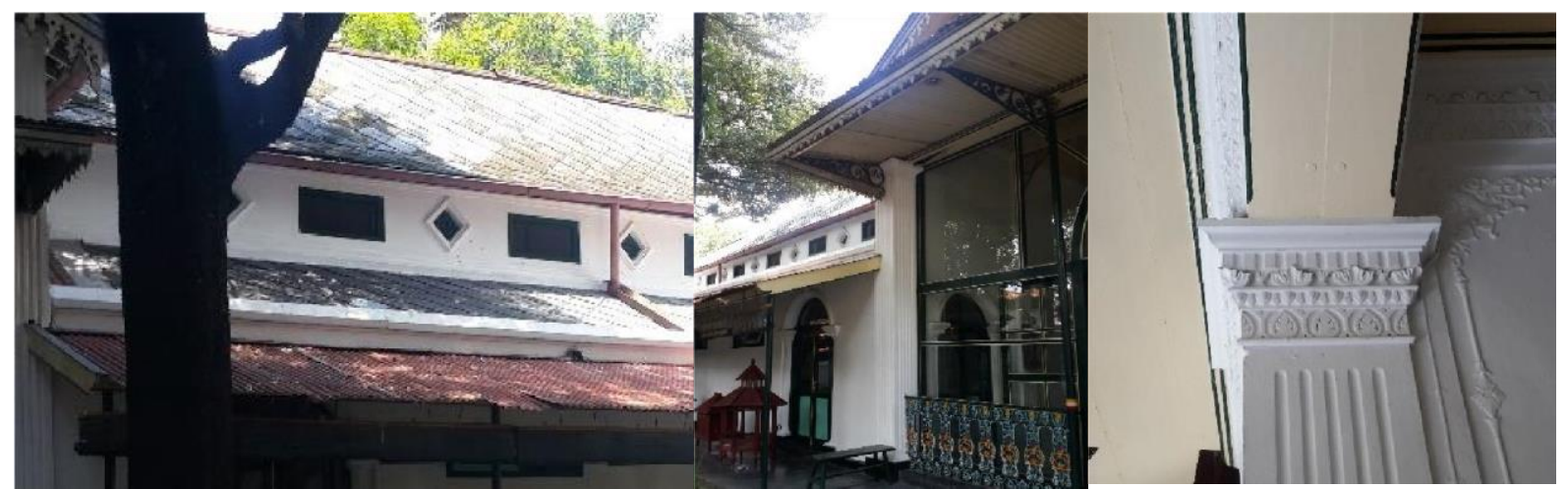

Figur 12. Contoh moulding pada Komplek Kasatriyan

\subsubsection{RAILING}

Railing pada pintu masuk kedua gedhong memiliki ciri yang sama terbentuk dari material besi. Ornamen pada railing memiliki pola repetisi floral dan wajah macan yang mencirikan budaya inggris. Sedangkan pada railing di sekitar regol kasatriyan dan sekeliling area menggambarkan pola kolom yang berdampingan dan pola floral. Kedua railing tersebut terdiri atas komposisi warna antara hijau, kuning, merah dan putih dengan dominasi warna hijau.

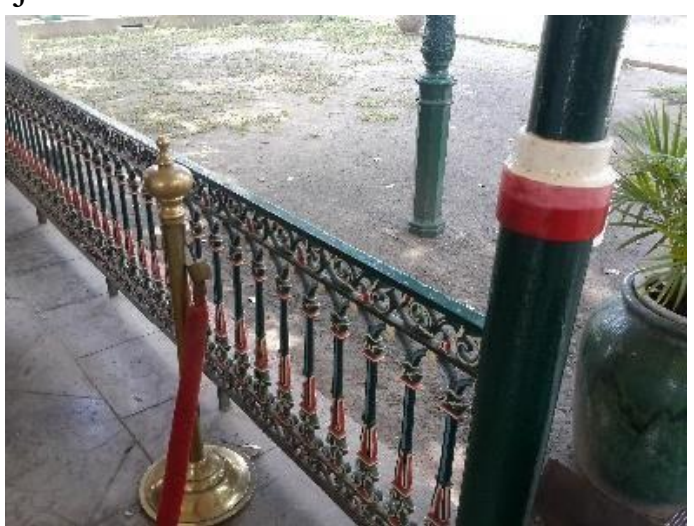

Figur 13. Railing Komplek Kasatriyan

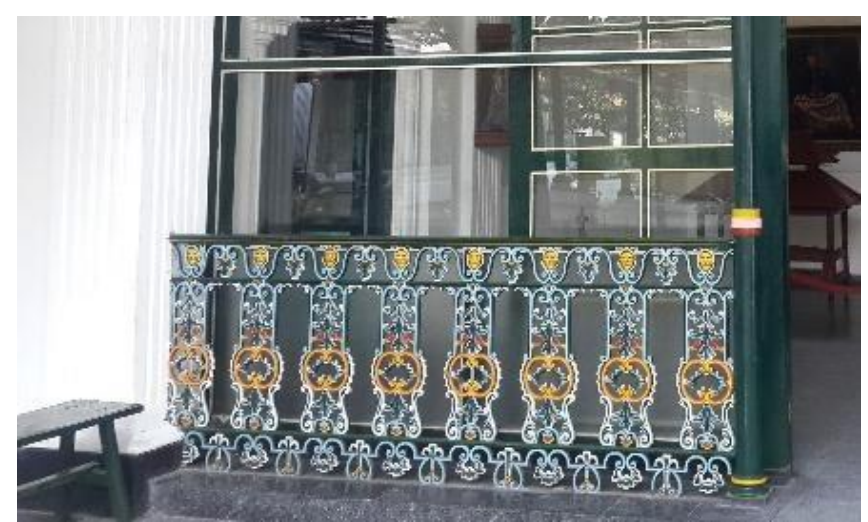

Figur 14. Railing Gedhong Maduretna

\subsubsection{KOLOM BESI}

Kolom besi pada Gedhong Pringgodani memiliki ciri kolom composite dengan ekspresi bentuk kepala kolom floral dan architrave berbentuk geometris dengan gaya ornamen floral berulang. Berbeda dengan kolom Yunani, kolom-kolom yang digunakan bermaterial besi seperti pada gaya arsitektur akhir tahun 1900 Indische Empire Style. 


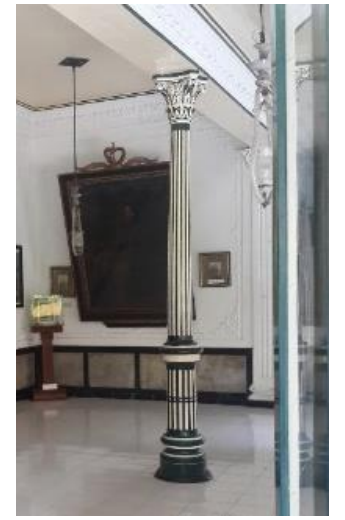

Figur 15. Kolom Gedhong Pringgodani

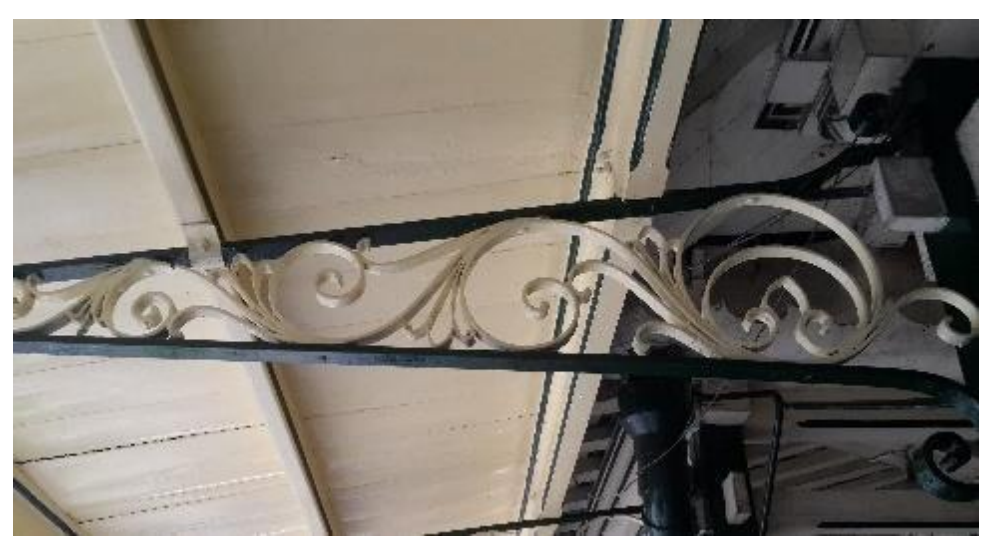

Figur 16. Konsol tambahan

\subsubsection{KONSOL}

Konsol pada kedua gedhong merupakan hasil penambahan atap pada tahun 1921 untuk memperpanjang teritis. Berfungsi untuk mengendalikan ketahanan bangunan terhadap cuaca. Konsol tersebut memilik pola floral yang terbuat dari besi.

\subsubsection{LISPLANG}

Terdapat dua jenis lisplang pada Komplek Kasatriyan, lisplang kayu berasal dari langgam Arsitektur Betawi dan lisplang tembaga yang berasal dari langgam Arsitektur Art Nouveau. Kedua bangunan mengaplikasikan kedua jenis lisplang, namun pada Gedhong Pringgodani lebih ditonjolkan lisplang dengan bahan tembaga, sedangkan pada Gedhong Maduretna terjadi sebaliknya.
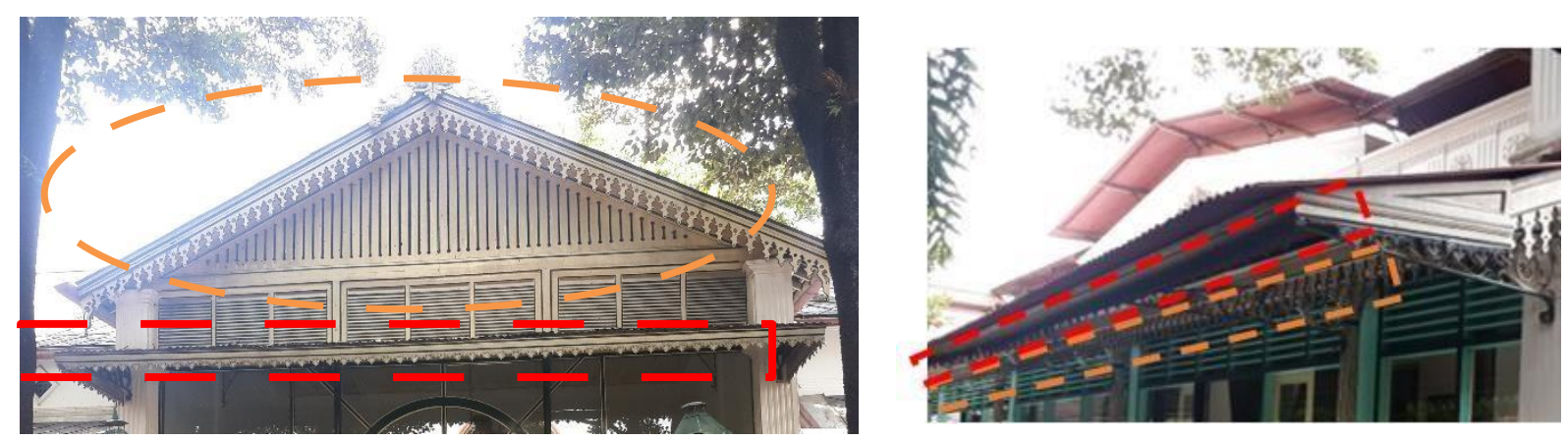

Figur 17. Lisplang Kayu (oranye) dan Lisplang Tembaga (merah)

\subsubsection{ATAP PELANA - PERISAI}

Gedhong Maduretna memiliki ciri bangunan kolonial yang kurang menyesuaikan dengan iklim lokal, dimana atap bangunan tidak memiliki teritisan yang panjang. Bentuk atap bangunan ini terbentuk atas penggabungan atap pelana dan perisai. Berfungsi sebatas untuk mengalirkan air menuju talang bangunan. Akibat dari kurangnya adaptasi terhadap cuaca lokal, maka kerusakan pada dinding bangunan akibat tampias air tidak terhidarkan.

Sedangkan bentuk atap pada Gedhong Pringgodani memberikan kesan seakan-akan terdapat penambahan atap pada entablature untuk mengakali pengendalian cuaca terhadap bangunan bergaya Neo-Klasik. Pada bagian bawah gevel juga diberi penambahan atap dengan struktur konsol yang menempel pada kolom bangunan. 


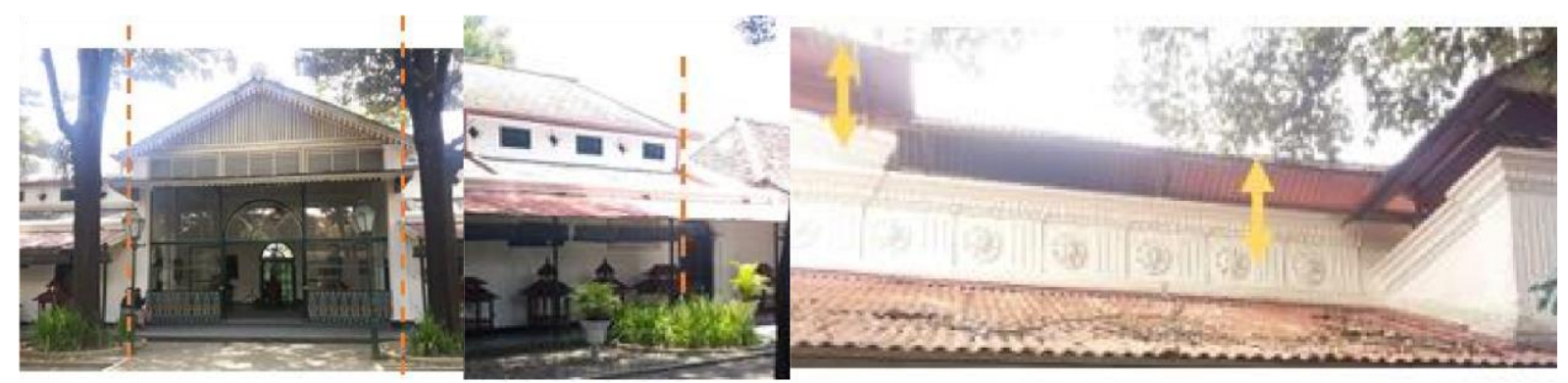

Figur 18. Bentuk Atap pada Museum Luksisan

\subsubsection{ORIENTASI BANGUNAN}

Orientasi Gedhong Maduretna menghadap Utara-Selatan, sedangkan Gedhong Pringgodani menghadap Barat-Timur. Maka dari itu perpanjangan teritisan pada Gedhong Pringgodani dimaksudkan untuk melindungi ruangan dari cahaya matahari langsung, juga untuk mengatasi tempias air hujan.

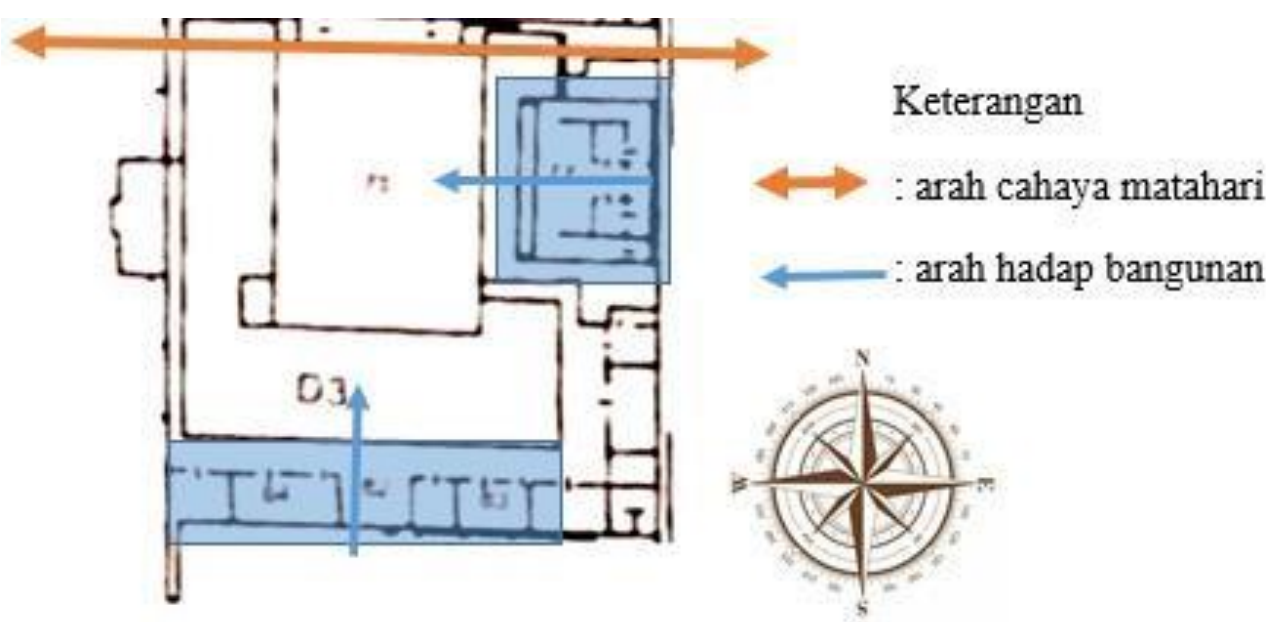

Figur 19. Arah Hadap Bangunan

\subsubsection{BENTUK DAN KEADAAN LINGKUNGAN}

Tapak Komplek Kasatriyan berada pada Keraton Yogyakarta, sehingga jauh dari gangguan lalu lintas, selain itu di dalam Keraton Yogyakarta tidak ada akses kendaraan untuk masuk ke hingga mencapai area Komplek Kasatriyan.

Bagian terdekat dari jalan merupakan Gedhong Pringgodani yang bersebelahan dengan Jl. Kasatriyan, namun jalan tersebut merupakan jalan kecil yang jarang dilalui oleh kendaraan, sehingga efek getaran kendaraan tidak mempengaruhi struktur dari bangunan, lebih lagi jalan tersebut dibatasi oleh dinding atau benteng yang sangat tebal untuk membatasi Keraton dengan pemukiman diluar. 


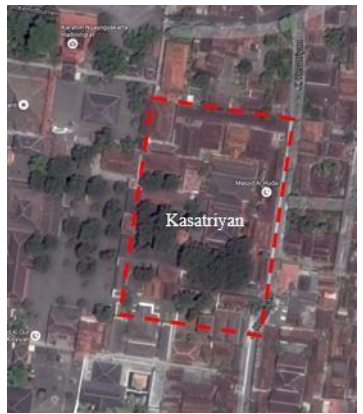

Figur 20. Site

\subsection{PERIODISASI ELEMEN KOMPLEK KASATRIYAN}

\subsubsection{TAHUN 1896 (TAHUN BERDIRI)}

Dibangun oleh Sultan Hamengkubuwono VII. Pada periode ini langgam arsitektur indis sudah diterapkan. Namun masih terdapat kekurangan pada adaptasi bangunan terhadap cuaca lokal. Sebagai akibatnya terdapat beberapa kerusakan, terutama pada dinding bangunan.

\subsubsection{TAHUN 1921-1934}

Pada tahun 1921 Sultan Hamengkubuwono VIII melaksanakan tindakan konservasi terhadap keseluruhan Komplek Keraton Yogyakarta. Pada Komplek Kasatriyaan terdapat penambahan elemen-elemen berupa tindak adaptasi bangunan terhadap cuaca, dimaksudkan agar kerusakan yang sebelumnya tidak terulang lagi.

(1) Penamabahan atap seng dengan struktur kolom besi/konsol besi dan struktur atap kaso kayu, pada Gedhong Pringgodani, Gedhong Maduretna, dan Bangsal Kasatriyaan

(2) Penambahan selasar dengan atap seng

(3) Penambahan ubin PC pada dinding interior Gedhong Pringgodani

(4) Penambahan Lisplang tembaga pada atap Gedhong Pringgodani.

\subsubsection{TAHUN 1988-1992}

Pada tahun 1988 Sultan Hamengkubuwono IX melakukan tindak konservasi terhadap Komplek Keraton Yogyakarta. Untuk meningkatkan nilai guna dari Komplek Kasatriyaan, terjadi perubahan fungsi menjadi sebuah museum. Terdapat juga penambahan elemen pada kedoa gedhong untuk mengadaptasikan keadaan dengan perubahan fungsi tersebut.

(1) Penambahan dinding partisi pada teras depan Gedhong Pringgodani.

(2) Penambahan dinding partisi pada ruang tengah Gedhong Maduretna.

(3) Penambahan lubang-lubang ventilasi pada ruang di dalam Gedhong Maduretna.

(4) Penambahan Pintu pada ruang tengah Gedhong Maduretna

(5) Penambahan acian semen dan penggunaan cat acrylic (pengganti cat kapur) pada hampir keseluruhan dinding di Komplek Keraton Yogyakarta

\subsubsection{TAHUN 1992-SEKARANG}

Kedua bangunan berfungsi sebagai sebuah museum lukisan. Kondisi kedua bangunan saat ini mengalami kerusakan-kerusakan minor, berupa:

(1) Kerusakan pada dinding, berupa bercak air dan penimbunan lumut.

(2) Kerusakan pada atap seng berupa lubang, memudarnya cat, dan penimbunan daun pada atap. 
(3) Kerusakan pencahayaan buatan dalam ruangan, tersimpan fitting lampu yang sudah tidak terpakai

(4) Penimbunan daun dan kotoran pada skylight Gedhong Maduretna

(5) Sudah mengalami pengecatan ulang pada dinding, plafond, dan ornamentasi bangunan.

(6) Kerusakan pada sirap asbes penutup atap Gedhong Maduretna.

\subsection{PEILAIAN PADA PENAMBAHAN ELEMEN BANGUNAN}

\subsubsection{PENAMBAHAN ELEMEN TAHUN 1921-1934}

Semua Penambahan elemen arsitektur pada tahun 1921-1934 memiliki Nilai Arsitektur berupa umur, adaptasi bangunan terhadap iklim tropis dan keragaman gaya arsitektur. Beberapa diantaranya juga memiliki Nilai Kekriyaan dalam teknik pembuatan elemen, sehingga semua elemen harus di konservasi sesuai keadaannya semula.

\subsubsection{PENAMBAHAN ELEMEN PADA TAHUN 1988-1992}

Penambahan elemen arsitektur pada tahun 1988-1992 merupakan hasil adaptasi bangunan terhadap perubahan fungsi. Tetapi bukan merupakan elemen signifikan yang harus di konservasi, sehingga bentuk elemen dapat terjadi perubahan.

\section{ANALISA KONSERVASI MUSEUM LUKISAN KOMPLEK KASATRIYAAN}

\subsection{KONSERVASI MUSEUM LUKISAN KOMPLEK KSATRIYAN}

Konservasi pada Museum Lukisan Komplek Kasatriyan bertujuan untuk memperpanjang umur bangunan sebagai sebuah peninggalan bersejarah. Tindakan konservasi memberikan maksud untuk meningkatkan nilai guna bangunan dengan mempertahankan suasana, aktivitas dan keotentikan bangunan, agar tetap dapat digunakan dan memberikan pembelajaran hingga masa yang akan datang.

Sebagai bangunan konservasi, Komplek Kasatriyan memiliki nilai-nilai yang terkandung, yaitu:

(1) Nilai Arsitektural: Merupakan bangunan dengan penggabungan keragaman langgam arsitektur, berupa Jawa, Neo-Klasik, Art Nouveau, dan Betawi. Saat ini sudah berumur lebih dari 100 tahun.

(2) Nilai Sejarah: Dibangun pada tahun 1896 sebagai sebuah sekolah untuk anak-anak sultan, juga sempat digunakan sebagai tempat tinggal anak Sultan. Lalu mengalami konservasi pada tahun 1921 oleh Sultan Hamnegkubuwono VIII. Pada tahun 1988 mengalami tindakan konservasi oleh Sultan Hamengkubuwono VII dengan upaya meningkatkan nilai guna bangunan. Sejak itu berfungsi sebagai sebuah museum lukisan.

(3) Nilai Kekriyaan: Terdapat diversitas ornamen yang melambangkan setiap langgam arsitektur. Konstruksi bangunan menggunakan material yang saat ini sulit untuk direka ulang cara pembuatannya. Selain itu, ornamen-ornamen tersebut memberikan sebuah makna tersendiri terhadap budaya yang kental di dalam Keraton Yogyakarta.

(4) Nilai Guna Bangunan: Mengalami perubahan fungsi, sebelumnya digunakan sebagai sekolah untuk anak-anak sultan dan sekarang menjadi sebuah museum karya dari sekolah kesultanan, sehingga Komplek Kasatriyan masih dapat digunakan beraktivitas. 
Adaptation and Conservation of the Fine Arts Museum in...

\subsection{PENETAPAN PERIODE BANGUNAN SEBAGAI ACUAN KONSERVASI}

Tabel 1. Periodisasi Komplek Kasatriyan

\begin{tabular}{|c|c|c|c|}
\hline 1896 & 1921-1934 & 1988-1992 & sekarang \\
\hline $\begin{array}{l}\text { Pendirian } \\
\text { Komplek } \\
\text { Kasatriyan }\end{array}$ & $\begin{array}{l}\text { Konservasi oleh } \\
\text { Sultan } \\
\text { Hamengkubuwono } \\
\text { VII }\end{array}$ & $\begin{array}{l}\text { Konservasi oleh } \\
\text { Sultan } \\
\text { Hamengkubuwono } \\
\text { VIII }\end{array}$ & Maintanance \\
\hline $\begin{array}{ll}\text { Sekolah } & \text { dan } \\
\text { Tempat tinggal } & \text { Putra } \\
\text { Mahkota } & \end{array}$ & $\begin{array}{ll}\text { Sekolah } & \text { dan } \\
\text { Tempat tinggal } & \text { Putra } \\
\text { Mahkota } & \end{array}$ & $\begin{array}{l}\text { Museum Lukisan dan } \\
\text { Kantor }\end{array}$ & $\begin{array}{l}\text { Museum Lukisan dan } \\
\text { Kantor }\end{array}$ \\
\hline
\end{tabular}

Bila dilihat dari tabel diatas dan sub-bab 3.2 (Periodisasi Elemen Komplek Kasatriyaan), setelah tindakan konservasi tahun 1921-1934 oleh Sultan Hamengkubuwono VIII, keseluruhan bangunan di Komplek Kasatriyan sudah beradaptasi terhadap cuaca lokal dengan baik. Lebih lagi nilai kesejarahan bangunan sebagai sebuah sekolah dan tempat tinggal putra mahkota masih tersimpan. Untuk itu penelitian ini bermaksud untuk mempertahankan nilai-nilai yang dimiliki Komplek Kasatriyaan sejak tahun 1934, tanpa mengurangi nilai guna bangunan saat ini sebagai museum lukisan.

\subsection{TINDAKAN ADAPTASI MUSEUM LUKISAN KOMPLEK KASATRIYAN 3.3.1 ADAPTASI GEDHONG MADURETNA 3.3.1.1 DINDING PARTISI}

Pintu utama Gedhong Maduretna merupakan penambahan yang dilakukan pada tahun 1988 (masa pemerintahan Sultan Hamengkubuwono IX). Fasad tersebut berfungsi agar benda- benda bersejarah di dalam bangunan yang berupa lukisan dan pajangan patung di dalamnya terjaga dari cuaca yang mampu merusak.

Saat ini terbentuk ambiguitas terhadap periode pembangunan dinding kaca dengan elemen di sekitarnya. Maka dari itu diperlukan perggantian struktur fasad dengan besi dan spider fitting sebagai struktur penahan kaca. Hal ini dimaksudkan agar terbentuk diferensiasi antara penambahan elemen baru dengan elemenelemen bersejarah.

Sebagai hasilnya, Gedhong Maduretna memiliki diferensiasi elemen antara ketiga periode secara jelas.

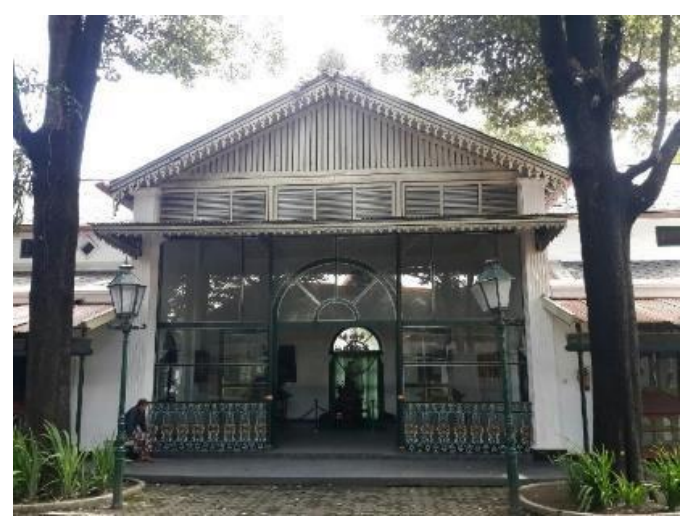

Figur 21. Pintu utama 


\subsubsection{TATA RUANG}
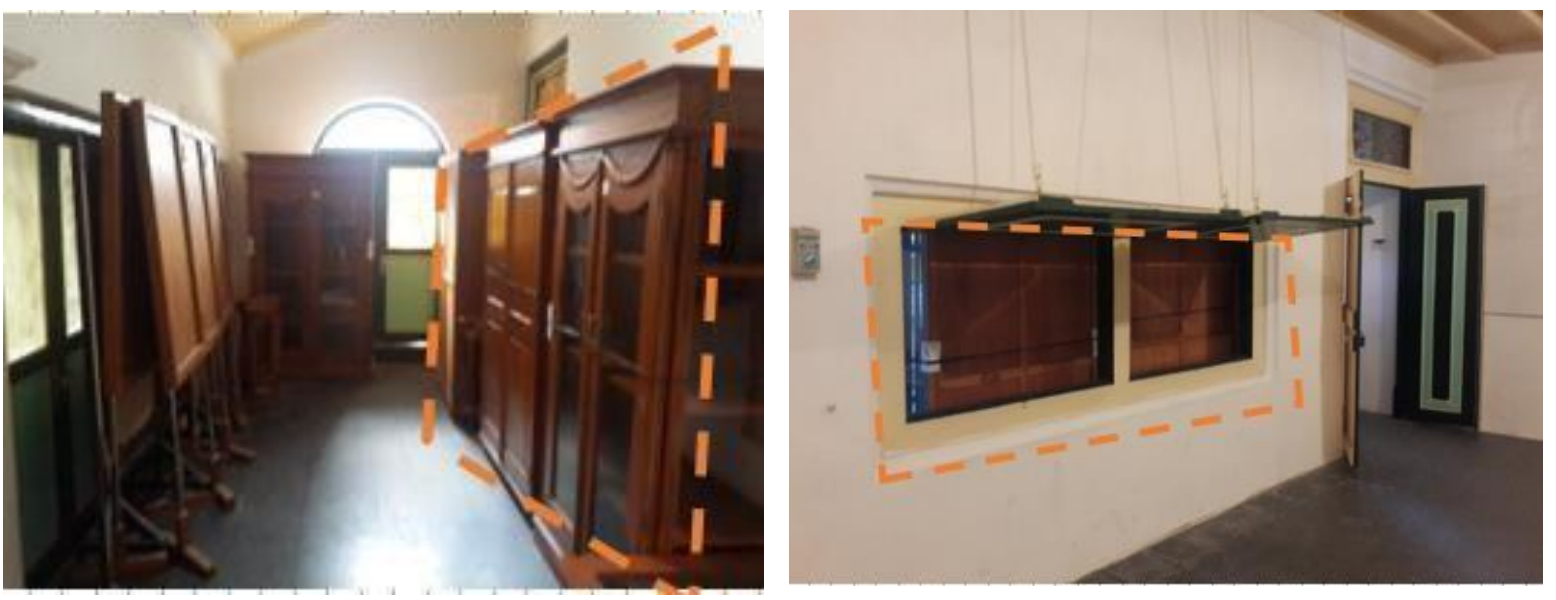

Figur 22. Lemari yang menghalangi pencahayaan ke dalam ruangan

Gambar di atas terletak pada sayap timur bangunan, atau pada ruang di timur bangunan. Dapat terlihat bahwa keadaan penghujung bangunan tidak difungsikan, sedangkan menjadi tempat penyimpanan lemari-lemari bekas. Efek yang berdampak pada ruangan tersebut adalah berkurangnya pencahayaan alami yang seharusnya mampu didapatkan dari bukaan tersebut. Berbeda dengan ruang di sebelahnya dimana penchayaan alami dapat masuk ke dalam ruangan.

Mencontoh dari ruang di sebelahnya, solusi yang dapat dilakukan adalah dengan memindahkan lemari-lemari pada pojok ruangan. Sehingga pintu di penghujung ruangan Gedhong Maduretna dapat dibuka, maka sirkulasi ruangan tidak lagi terganggu dan fungsi keseluruhan ruang menjadi lebih efektif.

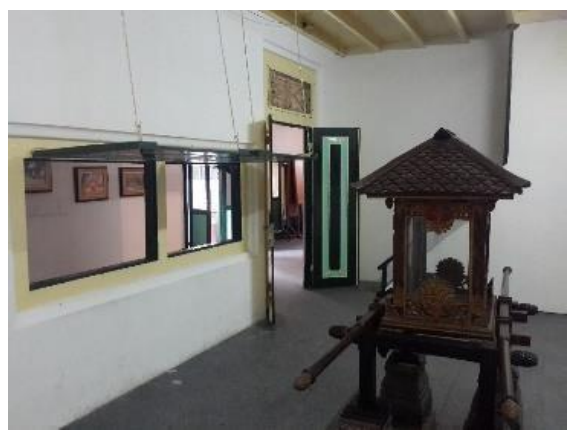

Figur 23. Kondisi ruang di sebelahnya

\subsubsection{PENCAHAYAAN BUATAN}

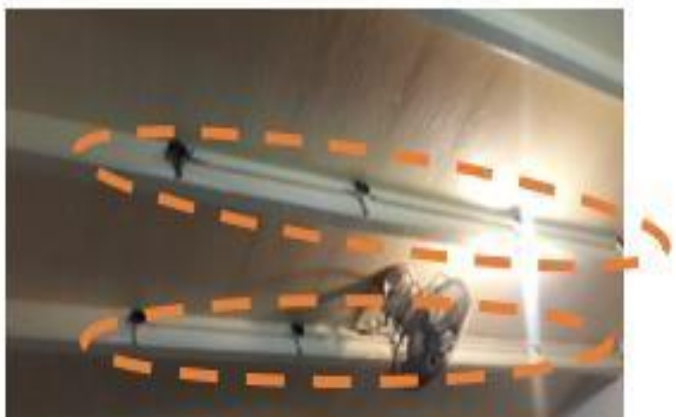

Figur 24. Fitting lampu terbengkalai 
Pada gambar tersebut terlihat fitting lampu dan kipas angin yang terpasangkan pada balok kayu sudah tidak lagi terpakai. Sebaiknya dilepaskan dan pencahayaan buatan pada ruang ditambahkan dengan lampu sorot pada balok yang dapat menyorot langsung ke setiap lukisan satu per satu, sehingga hasil karya memiliki pencahayaan yang kontras terhadap ruangnya.

\subsubsection{KENYAMANAN TERMAL}

Suhu udara rata-rata di Yogyakarta menunjukan $\pm 27^{\circ} \mathrm{C}$ di luar bangunan (Meteocast, 2016), Sedangkan Museum Lukisan dibuka untuk pengunjung pada saat suhu memuncak (Hari Senin - Kamis, 10.00-14.00), sehingga dapat dikatakan kurang nyaman untuk beraktivitas (suhu rata-rata >26,50C (suhu nyaman manusia), ditambah lagi tidak terbentuk cross ventilation sehingga kecepatan angin tidak dapat membantu merendahkan suhu kulit manusia, juga menciptakan tingkat kelembaban ruangan cukup tinggi. Solusinya adalah menggunakan $A C$ /penghawaan buatan untuk memberikan kenyamanan beraktivitas dan bertujuan memeliharaan objek benda pameran. Berfungsi untuk mengatur temperatur dan kelembaban yang diinginkan, sehingga pengguna bangunan pun dapat menikmati hasil pameran lebih lama dan tingkat ketahanan obyek pameran pun lebih tinggi.

Penghawaan buatan yang digunakan sebaiknya adalah standing AC. Sehingga tidak diperlukan penambahan dan penjebolan dinding untuk box exhaust, sedangkan hanya membutuhkan bukaan kecil atau jendela sebagai penempatan pipa exhaust.

\subsubsection{ADAPTASI GEDHONG PRINGGODANI}

\subsubsection{DINDING PARTISI}

Dinding ini merupkan sebuah penambahan pada tahun 1988 dengan bahan dasar kayu. Sayangnya penambahan dinding partisi ini menciptakan perubahan bentuk pada Gedhong Pringgodani. Ruangan yang sebelumnya merupakan sebuah teras dari bangunan, berubah menjadi ruang tertutup. Makna dari sebuah teras sebagai penyambut bangunan berubah menjadi ruangan yang terisolasi untuk menciptakan pertahanan terhadap pengaruh cuaca akan benda-benda di dalamnya.

Alternatif yang diusulkan terhadap dinding tersebut adalah dengan pembaharuan material menjadi dinding kaca. Kaca mampu memberikan kesan transparansi terhadap fasad tambahan, agar suasana ruang berkesan sebagai sebuah teras. Contoh yang dapat ditampilkan adalah seperti Gedhong Kaca yang pada tahun 1992 baru dibangun, terletak di selatan Komplek Kasatriyan.
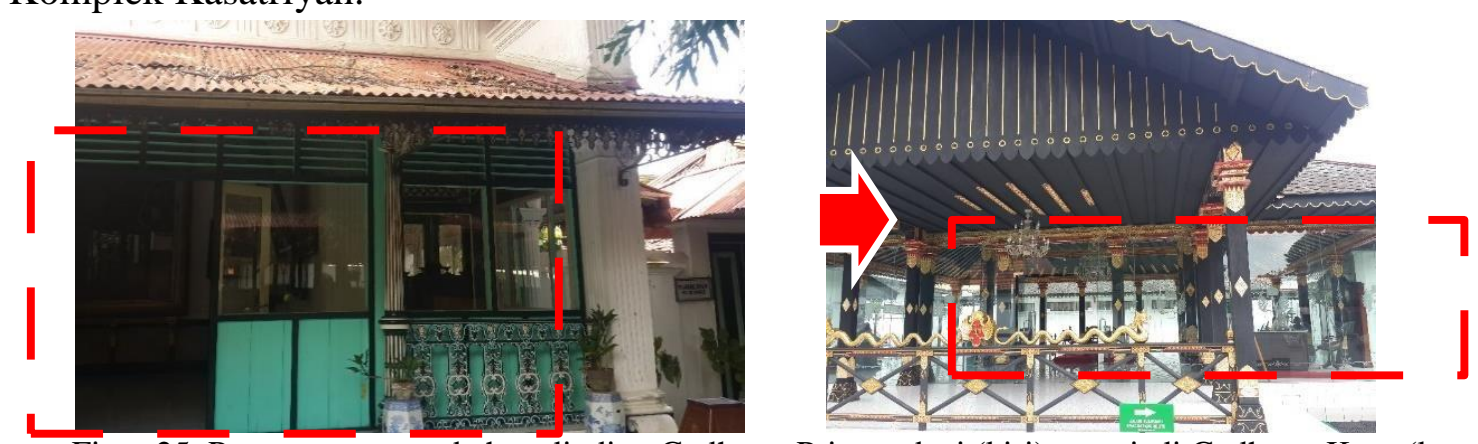

Figur 25. Perencanaan perubahan dinding Gedhong Pringgodani (kiri) menajadi Gedhong Kaca (kanan) 


\subsubsection{KENYAMANAN TERMAL}

Sama kondisinya dengan Gedhong Maduretna (iklim, suhu, kecepatan angin). Area pembahasan dari Gedhong Pringgodani merupakan sebuah teras. Sebelum ada penambahan dinding partisi, penghawaan terjadi dikarenakan keterbukaan ruang tersebut. Sayangnya, setelah penambahan dinding partisi pada tahun 1988, maka penghawaan dalam ruangan menjadi terhambat, hal ini dikarenakan tidak terjadinya cross ventilation.

Sehingga yang disarankan adalah dengan menggunakan AC pada ruangan, setelah dilakukan pergantian material dinding partisi menjadi dinding kaca. Lebih lagi, dinding Kaca menciptakan ruangan terisolasi dari kebocoran udara. Sehingga penggunaan AC akan menjadi lebih efektif. Solusi ini bertujuan agar pengguna bangunan pun dapat menikmati hasil pameran lebih lama dan tingkat ketahanan obyek pameran pun lebih tinggi. Penghawaan yang digunakan sebaiknya adalah standing $A C$.

\subsection{TINDAKAN PRESERVASI PADA MUSEUM LUKISAN KOMPLEK KASATRIYAN}

\subsubsection{TINDAKAN PRESERVASI GEDHONG MADURETNA}

\subsubsection{ATAP}

Penutup Atap Sirap Asbes. Perbaikan yang bias dilakukan adalah dengan mengganti sirap asbes dengan sirap asbes yang baru. Sirap asbes pengganti sebaiknya dilapiskan dengan coating anti-air terlebih dahulu dengan teknologi terkini agar tidak mengalami penimbunan lumut pada sirap.

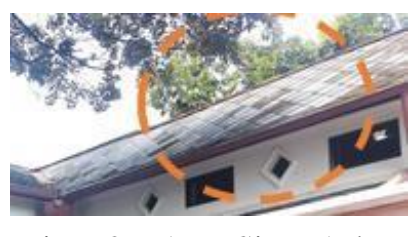

Figur 26. Atap Sirap Asbes

Skylight. Penimbunan kotoran pada kaca skylight cukup dilakukan pembersihan berkala setiap 1 tahun sekali.

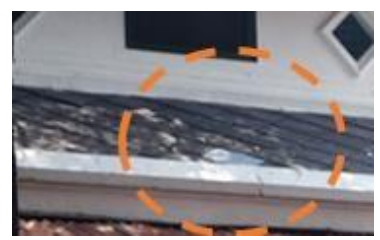

Figur 27. Skylight

Atap Modul Seng. Pada penambahan atap dengan modul seng, kerusakan pada seng apabila tidak terlalu parah cukup dengan melakukan pengecatan ulang dan coating anti-air agar dapat bertahan lebih lama.

\subsubsection{PLAFOND}

Plafond Kayu Jati. Struktur plafond pada Gedhong Maduretna merupakan susunan kayu jati yang sebagian sekaligus menjadi plat lantai 2 bangunan. Kondisi kayu masih sangat baik, karena baru saja dilakukan pengecatan pada saat pergantian fungsi menjadi sebuah museum. Cat yang digunakan berwarna glossy dengan maksud agar terjadinya pengendalian cahaya terhadap 


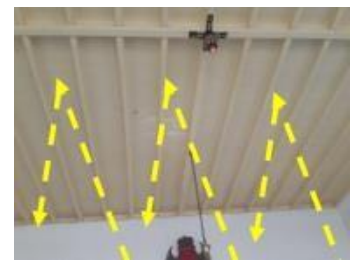

Figur 28. Pantulan Cahaya pada plafond

\subsubsection{DINDING}

Dinding Pemikul Batu Bata. Dinding Gedhong Maduretna menggunakan material berupa dinding pemikul bermaterial batu bata, batu bata ini merupakan komposisi antara batu merah, pasir dan kapur. Dinding-dinding tersebut sudah mengalami perbaikan dan penambahan acian beton.

Acian beton yang tidak sesuai mampu merusak keadaan dinding batu bata di dalamnya, karena pori-pori pada dinding tertutupi. Maka dari itu dibutuhkan perlakuan, pertama pengerokan cat dinding, kedua pengerokan acian beton, ketiga mengganti lapisan acian mortar berpori, terakhir PC penggunaan cat akrilik kualitas tinggi(batu bata masih dapat "bernafas").

Dinding dengan ubin PC. Pada dinding interior bangunan terdapat penambahan ubin PC sejak tahun 1921 berfungsi sebagai penutup bercak air akibat tempias air dan tempat bertumpu lukisan-lukisan. Perawatan yang dapat dilakukan adalah dengan membersihkan ubin secara berkala dengan lap basah, agar tidak terjadi penimbunan debu.

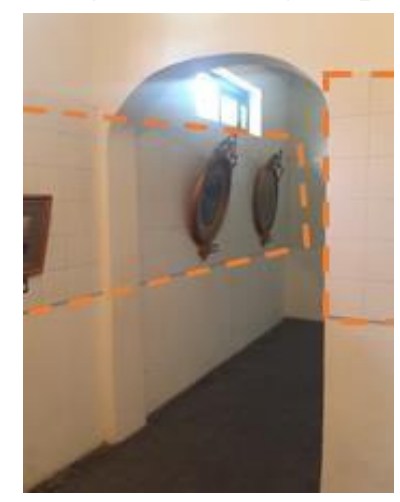

Figur 29. Dinding dengan ubin

\subsubsection{BUKAAN}

Kusen Kayu. Bila kusen kayu ada beberapa yang mulai mengelupas, penanganan kusen kayu dapat dilakukan dengan pengisian woodfiller kemudian dilapiskan politur atau cat akrilik, lalu finishing dengan coating anti air.

Lubang-Lubang Ventilasi. Biasanya yang terjadi adalah penumpukan debu, atau masuknya serangga. Sebaiknya dilakukan penutupan lubang dengan wiremesh dan dilakukan pembersihan berkala setiap minggunya.

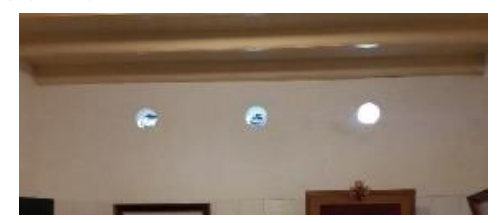

Figur 30. Lubang ventilasi 
Gevel Kayu. Pada gambar diatas, terlihat bahwa warna cat kayu pada bagian gevel dan jalusi sudah mulai pudar dan diperlukannya pengecatan ulang terhadap material tersebut. Sebelum dilakukan pengecatan perlu dibersihkan terlebih dahulu dari debu yang menempel dengan menggunakan kuas atau kemoceng. Gevel dan jalusi yang berada pada ketinggian diatas 3m, maka diperlukan bantuan scaffolding untuk menjangkau area tersebut.

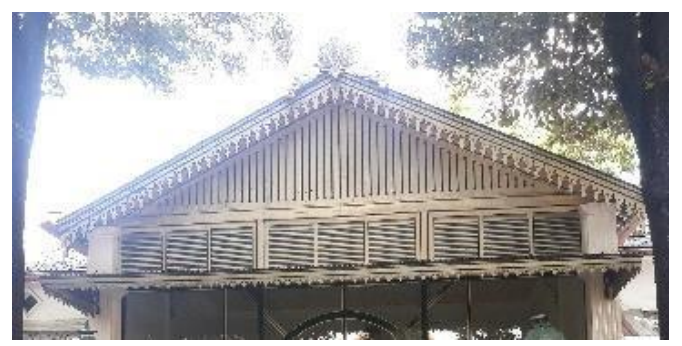

Figur 31. Gevel Gedhong Maduretna

\subsubsection{PINTU DAN BOUVENLICHT}

Kusen dengan Moulding. Pada hampir sebagian besar dari pintu di Gedhong Maduretna memiliki moulding pada bagian kusen pintu. Ciri tersebut menggambarkan gaya bangunan pada era kolonial. Pada dasarnya yang terjadi adalah penumpukan debu, yang menjadi noda hitam seperti pada dinding bangunan.

Tindakan rehabilitasi juga sebaiknya dilakukan pada pintu-pintu dengan penambahan warna cat hijau tosca. Sebaiknya menggunakan Pintu di Museum Lukisan warna kuning yang sudah dipakai pada kusen dan elemen lainnya agar terbentuk keserasian warna pada keseluruhan elemen.

Bouvenlicht. Bagian bouvenlicht terdiri dari besi dan kawat besi. Debu akan menempel dan menumpuk pada kawat besi, maka sebaiknya dilakukan penghisapan dengan vacuum cleaner.

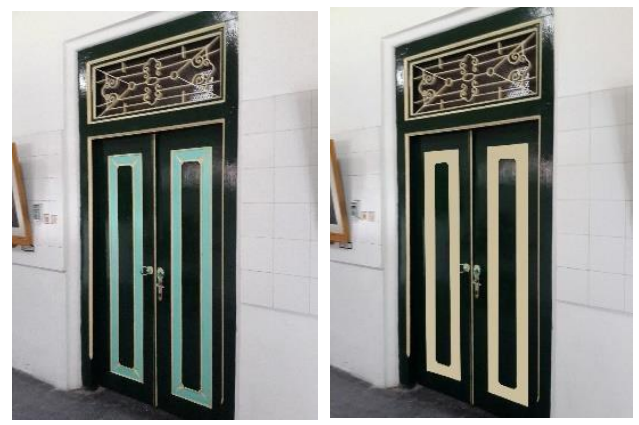

Figur 32. Perubahan Warna Cat Pada Pintu

\subsubsection{KONSOL}

Konsol pada bangunan menggunakan material besi yang bertumpu pada kolom-kolom berupa dinding pemikul. Konsol tersebut memiliki aspek estetis berupa perkuatan yang berpola floral dan berwarna hijau dan kuning. Bila terjadi kerusakan berupa karat atau patah pada struktur konsol, maka yang harus dilakukan adalah pengelasan dan pemolesan, lalu dicat kembali dengan cat besi.

\subsubsection{ORNAMEN}

Geveltoppen. Bahan material tersebut berupa kuningan, maka yang mungkin terjadi 
adalah patah, keropos, oksidasi atau bengkok. Maka yang perlu dilakukan adalah pembersihn dan pemolesan.

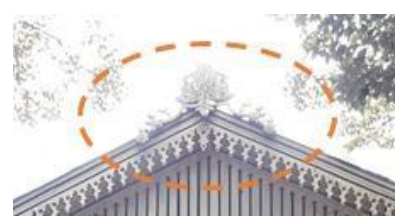

Figur 33. Geveltoppen

Railing. Pada dinding kaca terdapat railing yang digunakan sebagai ornamen bangunan. Merupakan ornamen yang sudah ada sejak awal pembangunan. Kondisi saat ini masih sangat baik, yang perlu dilakukan hanyalah pengecatan berkala setiap 5 tahun sekali.

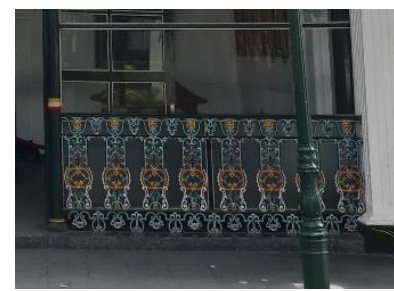

Figur 34. Railing Gedhong Maduretna

Lisplang Kayu. Terdapat juga ornament berupa lisplang dengan bahan kayu bergaya arsitektur Betawi. Lisplang tersebut masih dalam keadaan baik, hanya warna saja yang sudah mulai memudar, maka perlu dilakukan pengecatan ulang lalu pemberian pelitur. Pengawasan terhadap warna cat sebaiknya dilakukan setiap 5 tahun sekali karena lisplang selalu terpapar oleh sinar matahari dan air hujan.

Ornamen Kuningan. Ornamen berbahan kuningan yang terlihat pada gambar diatas terletak pada plafond ruang tengah. Keadaannya hingga saat ini masih dalam kondisi baik, yang perlu dilakukan hanya dengan pembersihan dari debu setiap seminggu sekali. Kerusakan jarang terjadi pada ornamen ini karena tidak terpapar oleh sinar matahari, namun apabila warna sudah mulai memudar, maka diperlukan pengecatan kembali dengan cat besi.

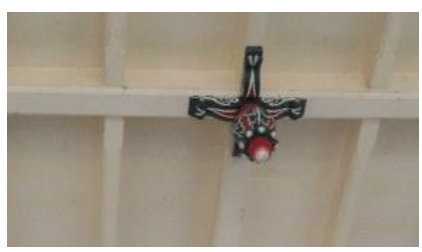

Figur 35. Oramen Kuningan

\subsubsection{LANTAI}

Ubin Batu Alam. Pada bangunan ini lantai menggunakan ubin batu alam (andesit), karena sebelumnya sempat digunakan sebagai area servis maka digunakan material yang tahan air dan kelembaban. Tidak ditemukanny kerusakan, sehingga yang dapat dilakukan adalah pembersihan berkala.

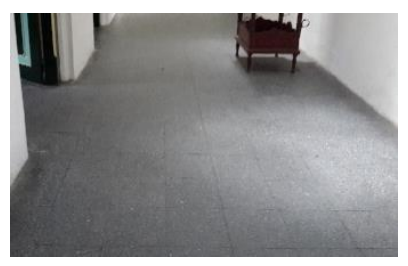

Figur 36. Ubin batu alam 


\subsubsection{TINDAKAN PRESERVASI GEDHONG PRINGGODANI}

\subsubsection{ATAP}

Terlihat dari foto, akibat pohon eksisting yang berada sangat dekat dengan bangunan, maka terjadi penimbunan daun-daun dan ranting pohon. Selain itu juga warna dari penutup atap modul seng sudah mulai pudar. Perbaikan dapat dilakukan dengan pengecatan ulang, atau dengan mengganti modul seng dengan material yang sama.

Apabila terjadi kerusakan minor pada Lisplang kayu, perbaikan dapat menggunakan perlakuan seperti pendempulan dengan serbuk kayu atau ketam kayu hasil pengerjaan, lalu menggunakan resin sebagai perekat, hal ini dilakukan untuk menambal bagian yang hilang dari kayu. Untuk perawatannya sendiri hanya dengan pengecatan politur/cat akrilik atau coating anti air minimal 5 tahun sekali. Alat yang digunakan terhadap bahan ini sebaiknya lembut, seperti dengan menggunakan kuas atau sprayer dalam pengecatannya. Teknik yang sama dapat dilakukan pada lisplang tembaga. Hanya apabila terjadi kerusakan yang besar, lisplang dapat diganti hanya dengan material yang sama.

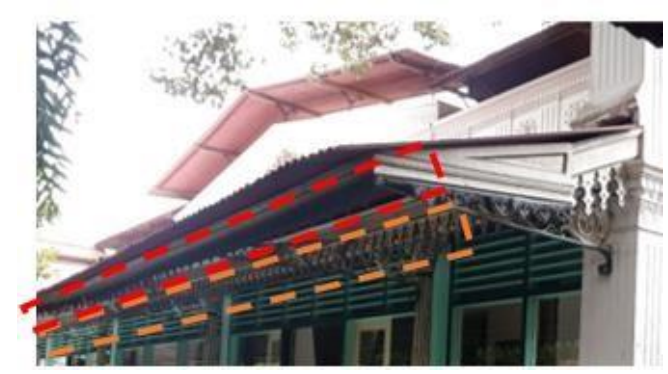

Figur 37. Lisplang Gedhong Pringodani

\subsubsection{GEVEL}

Gevel. Gevel bangunan dengan ornamen - ornamennya nampak masih dalam kondisi prima dengan bantuan penambahan atap pelana. Pada gambar terlihat ada sebagian noda hitam akibat tampias air hujan, penanganannya dapat dilakukan seperti pada dinding Gedhong Maduretna dan Regol Kasatriyan, yaitu dengan pembersihan cat dari noda menggunakan kuas dan pengecatan ulang. Ketinggian gevel akan menjadi masalah dalam perbaikannya, sehingga sebaiknya menggunakan scaffolding.

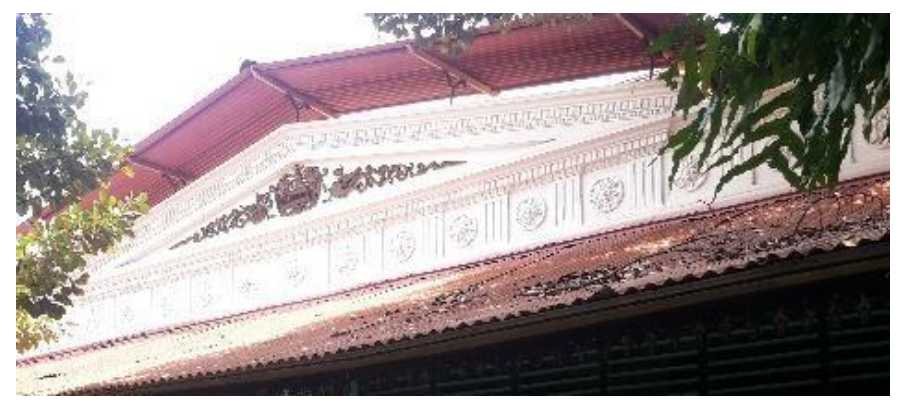

Figur 38. Gevel Gedhong Pringodani

\subsubsection{PLAFOND}

Plafond Kayu Jati. Plafond Gedhong Pringgodani memiliki material dan finishing yang sama dengan Gedhong Maduretna, yaitu material kayu dengan cat berwarna cerah 
untuk memantulkan cahaya matahari agar ruangan bersifat terang. Kerusakan jarang sekali terjadi, sehingga yang dilakukan dapat dalam bentuk perawatan berupa pengecatan.

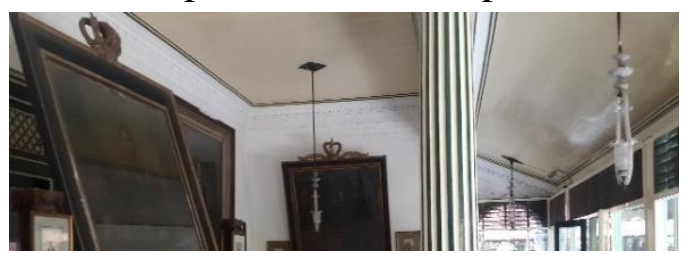

Figur 39. Plafond Kayu Gedhong Pringgodani

\subsubsection{DINDING}

Dinding Batu Bata. Sama halnya dengan dinding pada Gedhong Maduretna, dinding pemikul batu bata ini sudah mengalami penambahan acian beton yang mampu merusak dinding, akibat ketidaksesuaian material dengan material pembentuk strukturnya. Material batu bata bersifat porus, sehingga diperlukan lapisan selain acian beton yang berpori, agar batu bata dapat "bernafas".

Kolom dan Dinding. Kolom dan dinding Gedhong Pringgodani merupakan dinding pemikul dengan material batu bata. Kondisi saat ini memiliki noda-noda hitam dan lumut akibat air hujan. Sebagai perbaikannya dapat dilakukan dengan pembersihan noda-noda hitam dengan kuas atau dilakukan pengerokan, lalu dicat ulang dengan bahan cat akrilik. Pemilihan cat akrilik harus yang berkualitas tinggi agar bangunan dapat "bernafas".

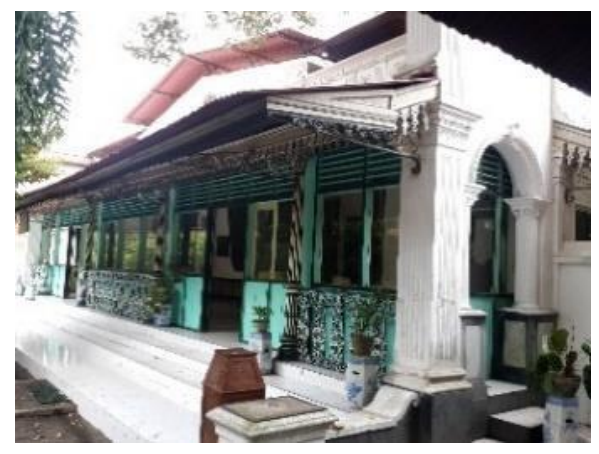

Figur 40. Dinding Gedhong Pringodani

Dinding Interior. Pada dinding interior terdapat keunikan dimana setiap dinding memiliki ukiran-ukiran yang nampak seperti pigura dan bagian bawah dinding tersebut ditutupi dengan veneer bermaterial marmer dan kayu, kedua elemen tersebut bertujuan untuk menambah unsur estetis bangunan dan menciptakan suasana bangunan kolonial, namun kerugiannya menjadi tempat dimana debu dapat bersarang dan menyebabkan kerusakan pada dinding. Perawatan yang perlu dilakukan hanyalah dengan membersihkan debu dengan lap kering atau kemoceng. Selain itu apabila timbul bercak air akibat kebocoran atap, yang dilakukan dapat hanya dengan pengecatan ulang dinding. 


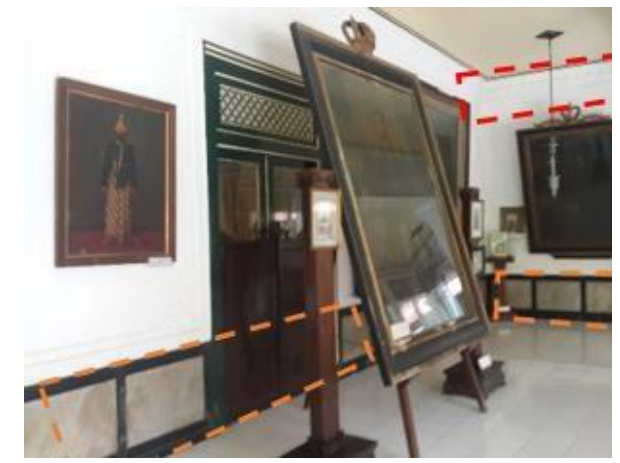

Figur 41. Dinding Interior Gedhong Pringodani

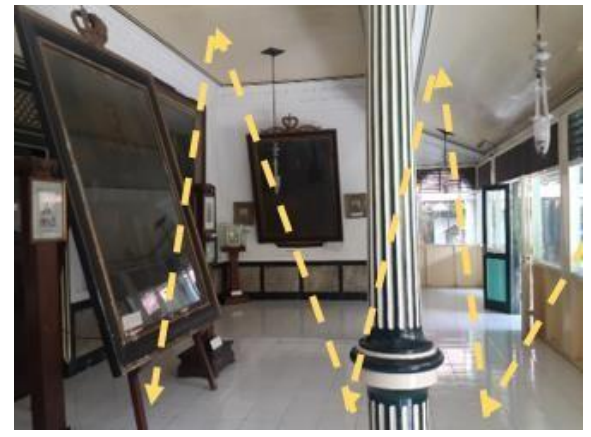

Figur 42. Pantulan cahaya pada Interior Gedhong Pringgodani

\subsubsection{LANTAI}

Ubin PC. Lantai menggunakan ubin PC dengan warna putih. Tampak pada gambar bahwa penutup lantai bangunan masih berkondisi baik adanya. Apabila terjadi kerusakan seperti pecah atau lepas, sebaiknya naad menggunakan mortar yang sama dengan material sebelumnya. Sedangkan, sebagai perawatan sebaiknya dilakukan setiap hari dengan mengepel lantai agar debu tidak metumpuk.

\subsubsection{KOLOM}

Kolom Besi. Kolom besi terdapat di dalam Pringgodani dan di luar bangunan, dan beberapa digunakan sebagai penopang konsol besi untuk perpanjangan teritis. Keseluruhan kolom terlindungi dari tampias air dengan adanya perpanjangan teritis, sehingga tidak mudah mengalami kerusakan. Kemungkinan yang terjadi adalah pudarnya warna kolom akibat paparan sinar matahari langsung.

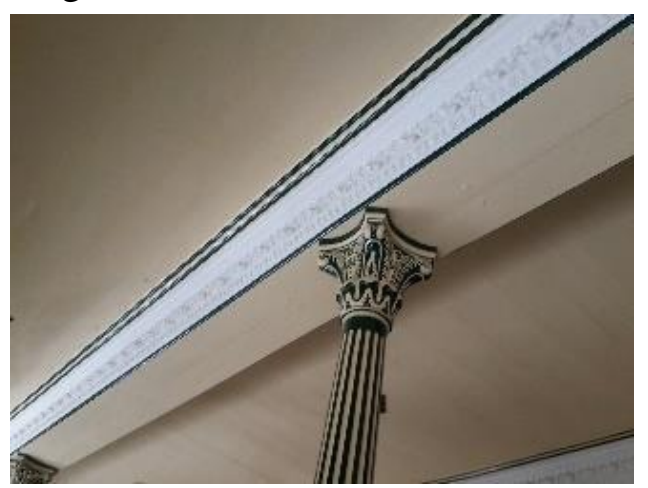

Figure 43. Kolom dan entablature Gedong

\section{PENUTUP}

\subsection{KESIMPULAN}

Museum Lukisan Komplek Kasatriyan merupakan salah satu bangunan di kawasan bersejarah Keraton Yogyakarta. Saat ini masih difungsikan sebagai area wisata lokal maupun internasional untuk melihat karya seni dan lukis di Keraton. Keunikannya bangunan ini memiliki penggabungan beberapa elemen dari berbagai langgam arsitektur, hal tersebut dapat dilihat dari elemen pembentuk bangunannya. Diversitas elemen yang ada berasal dari langgam Art Nouveau, Indische Empire Style, unsur lokal, dan arsitektur Betawi. Sebagai satu kesatuan Kompleks Kasatriyan, terdapat keunikan dimana perpaduan antara bangunan indis dengan 
bangunan arsitektur Jawa dapat berdiri dengan harmonis di satu area yang sama. Maka dari itu dapat disimpulkan bahwa Museum Lukisan ini masih menyimpan nilai-nilai penting, berupa nilai arsitektur, nilai sejarah, nilai kekriyaan, dan nilai guna bangunan yang pantas untuk dipertahankan.

Tahun 1921 menjadi acuan tindakan konservasi, karena bangunan merupakan fungsi awal pembangunan, yaitu sekolah dan tempat tinggal putra mahkota, lebih lagi kedua bangunan sudah beradaptasi dengan baik terhadap lingkungannya

Penambahan elemen arsitektur pada tahun 1988-1992 merupakan hasil adaptasi bangunan terhadap perubahan fungsi. Tetapi bukan merupakan elemen signifikan yang harus di konservasi, sehingga bentuk elemen dapat terjadi perubahan.

Dari keadaan bangunan saat ini maka dapat ditentukan tindakan yang tepat, antara lain: (1) Adaptasi dilakukan untuk memperjelas perbedaan periode setiap elemen bangunan, menciptakan suasana ruangan yang diinginkan dan meningkatkan kenyamanan beraktivitas dalam bangunan.

(2) Preservasi, rehabilitasi, dan restorasi dilakukan untuk memperbaiki kerusakan minor, memelihara ketahanan bangunan terhadap lingkungan, dan menciptakan kesan serupa pada elemen dengan awal pembuatannya.

\subsection{SARAN}

Sebagai sebuah Museum Lukisan, sebaiknya beberapa elemen kecil yang sangat mendukung fungsi karya-karyanya diperhatikan, seperti misalnya pencahayaan alami dan buatan perlu diperhatikan agar efek kontras antara karya dengan ruangan dapat terasa. Selain itu, sebaiknya keterangan terhadap kesejarahan setiap karya ditampilkan, agar pengunjung Museum Lukisan tidak hanya sekedar melihat hasil karya, namun dapat memahami dan mendapatkan pengetahuan akan sebagian kesejarahan dari Keraton.

\section{DAFTAR PUSTAKA}

Awal, H. (2011). Pengantar Panduan Konservasi Bangunan Bersejarah Masa Kolonial. Jakarta: Pusat Dokumentasi Arsitektur

Ching, FDK. (1979). Form, Space and Order. New York: Van Nostrand Reinhold Company. Hartono, Dibyo. (1999). Konservasi Interior Bersejarah. Bandung: ITB.

Hoego, Juanita A., 2009. Perawatan Bangunan Konservasi GPIB Bethel Wastukencana. Bandung. Lamdhanyskrip, Wilhelme B. (2010). Museum Budaya di Pontianak.

Robson, O. Stuart. (2003). The Keraton: Selected Essays on Javanese Courts. Netherlands: KITLV Press.

Sombu, Alwin S. (2012). Pelestarian Arsitektur Museum Sonobudoyo Yogyakarta. 